\title{
Formulasi Strategi Peningkatan Mutu Institut Agama Islam Negeri (IAIN) di Jawa Timur
}

\author{
Prim Masrokan Mutohar
}

IAIN Tulungagung, pmutohar@gmail.com

\begin{abstract}
Abstrak: Penelitian ini ingin mengkaji tentang formulasi strategi peningkatan mutu IAIN di Jawa Timur yang difokuskan pada: (1) penguatan bidang akademik (core activities of Higher Education); dan (2) Penguatan bidang non-akademik (supporting activities of Higher Education) dalam meningkatkan mutu IAIN. Perkembangan ilmu pengetahuan dan teknologi di era-global yang terjadi pada saat ini membawa dampak terjadinya perubahan dalam kehidupan manusia dan segala permasalahannya dapat diselesaikan dengan adanya penguasaan ilmu pengetahuan dan perkembangan tehnologi. Kondisi ini menuntut IAIN di Jawa Timur agar mampu merespon secara positif dan dapat meningkatkan mutu serta dapat merespon kebutuhan stakeholder dan perkembangan ilmu pengetahuan dan tehnologi secara positif. Agar IAIN mampu memenuhi tuntutan dan kebutuhan stakeholder serta berperan secara dinamis dalam persaingan global, maka perlu membuat formulasi strategi peningkatan mutu lembaga dengan baik. Formulasi strategi ini dapat dijadikan sebagai upaya untuk membuat perencanaan strategis yang dilakukan secara terencana, terarah, intensif, efektif, dan efisien dalam proses peningkatan mutu IAIN di era global yang terjadi pada saat ini.
\end{abstract}

Abstract: This study wants to examine the formulation of the strategy for improving the quality of IAIN in East Java which is focused on: (1) strengthening the academic field (core activities of Higher Education); and (2) Strengthening the supporting activities of Higher Education in improving the quality of IAIN. The development of science and technology in the global era that occurs at this time brings the impact of changes in human life and all the problems can be solved by the mastery of science and the development of technology. This condition requires IAIN in East Java to be able to respond positively and can improve quality and can respond to stakeholder needs and the development of science and technology positively. In order for the IAIN to be able to meet the demands and needs of stakeholders and play a dynamic role in global competition, it is necessary to formulate a strategy to improve the quality of the institution properly. The formulation of this strategy can be used as an effort to make strategic planning carried out in a planned, directed, intensive, effective, and efficient manner in the process of improving the quality of IAIN in the current global era. 


\section{A. PENDAHULUAN}

Era globalisasi yang terjadi pada saat ini terdapat berbagai perubahan dalam kehidupan masyarakat dunia yang dapat menghantarkan terjadinya mega kompetisi antar bangsa dalam berbagai aspek kehidupan. Kondisi ini membuat Negara-Negara maju telah mempersiapkan diri dengan membuat program-program unggulan dan strategis yang dapat mendukung dalam peningkatan mutu sumberdaya manusia. Program-program unggulan didesain dan dikembangkan berdasarkan tuntutan dan kebutuhan masyarakat dunia sebagai akibat arus globalisasi agar mempunyai daya saing yang tinggi. Program-program tersebut dirancang, dikembangkan, dan diimplementasikan di lembaga pendidikan agar menjadi bermutu dan diminati oleh masyarakat. Penyelenggaraan pendidikan yang bermutu dapat dijadikan sebagai dasar dan upaya untuk meningkatkan mutu sumberdaya manusia. Amerika Serikat sejak tahun 2001 telah mencanangkan program "No Child Left behind" untuk mengejar ketertinggalan dengan negaranegara Eropa (Mutohar dan Masduki, 2018:5). Singapura juga telah melakukan reformasi pendidikan dengan menitikberatkan pada keefektifan sistem pendidikan pada setiap jenis dan tingkatan pendidikan yang ada. Pelaksanaan reformasi pendidikan yang ada di Singapura dimulai dari tingkat sekolah ke tingkat nasional (Thingking School, Learn Nation) yang didasarkan pada "The goal of broad-based educational outcomes", dalam konteks ini kurikulum pendidikan di Singapura dibuat fleksibel sehingga dapat memberikan layanan kebutuhan siswa sesuai dengan tingkat perbedaan sikap, watak, kecerdasan yang dapat mendukung keterampilan berfikir siswa, kerja kelompok dalam satu tim, menyediakan satu komputer untuk dua orang siswa, menyediakan akses internet di sekolah, serta adanya dukungan yang kuat dari pemerintah yang diwujudkan dalam bentuk kebijakan pendidikan (Sharpe, L. \& Gopinathan, S., 2002:151-166).

Tuntutan arus globalisasi dan respon yang diberikan oleh setiap Negara maju untuk mengadakan inovasi dan peningkatan kualitas mutu pendidikan merupakan langkah strategis yang ditempuh dalam mempersiapkan sumber daya manusia yang berkualitas. Kondisi ini juga direspon oleh bangsa Indonesia yang tidak mau ketinggalan dengan negara-negara lain untuk menata dan meningkatkan mutu pendidikan agar mempunyai daya saing pada tataran global. Upaya yang dilakukan oleh bagnsa Indonesia dalam meningkatkan mutu pendidikan tinggi mulai dilaksanakan dengan adanya ketetapan tentang standar nasional pendidikan tinggi yang bertujuan untuk mendorong agar perguruan tinggi dapat mencapai mutu pembelajaran, penelitian, dan pengabdian kepada masyarakat secara berkelanjutan dapat melampaui kriteria yang ditetapkan dalam Standar Nasional Pendidikan Tinggi (Peraturan Menristek Dikti No 44 Tahun 2015 Pasal 3 ayat 1 tentang Standar Nasional Pendidikan Tinggi).

Perbaikan mutu pendidikan tinggi yang ada pada saat ini harus dilakukan dengan penataan kelembagaan pendidikan tinggi dengan manajemen yang baik dan tepat agar tujuan pendidikan dapat tercapai secara efektif dan efisien. Untuk bisa mewujudkan hal tersebut, setiap rektor sebagai pemimpin pendidikan di perguruan tinggi mempunyai tanggung jawab untuk dapat mengelola lembaga perguruan tinggi dengan baik. Kondisi ini diupayakan agar lembaga pendidikan tinggi dapat menjadi lembaga pendidikan yang maju, unggu, kompetitif, dan mempunyai daya saing yang tinggi. Perguruan tinggi yang dikelola dengan baik akan menjadi perguruan tinggi yang bermutu, sehingga bisa menghasilkan lulusan yang berkualitas dan diminati oleh stakeholder pendidikan. Lulusan perguruan tinggi yang berkualitas merupakan harapan dan tuntutan masyarakat serta stakeholder pendidikan. Masyarakat dan stakeholder pendidikan menjadi puas terhadap mutu dan kulaitas pendidikan tinggi, sehingga mampu memberikan dukungan yang baik terhadap pelaksanaan pendidikan dan pembelajaran di Perguruan Tinggi. Pendidikan bermutu adalah pendidikan yang mampu mengembangkan kemampuan, membentuk karakter, dan peradaban bangsa (Khoiri, 2016:75)

Manajemen organisasi lembaga pendidikan tinggi yang efektif, semakin banyak mendapatkan perhatian dan pengakuan dari berbagai pihak, baik internal maupun eksternal, sehingga perlu adanya perbaikan secara terusmenerus agar menjadi baik dan berkualitas. Lembaga pendidikan Islam, mulai dari pendidikan dasar hingga perguruan tinggi harus dikelola dengan baik agar menjadi lembaga yang efektif dan diminati oleh masyarakat. Berdasarkan beberapa hasil penelitian sebagaimana dijelaskan oleh Sammon menunjukkan bahwa kualitas kepemimpinan dan manajemen yang diterapkan dalam sistem organisasi dapat membedakan antara lembaga pendidikan yang bermutu dan lembaga pendidikan yang belum atau tidak bermutu (Bush \& Coleman, 2000:16). Kajian tersebut menunjukkan bahwa leader mempunyai peran kunci yang sangat strategis dalam meningkatkan mutu pendidikan di perguruan tinggi. Kualitas pendidikan yang ada di perguruan tinggi sangat dipengaruhi oleh penerapan manajemen yang baik di dalamnya (Mutohar, 2013:37). Pendidikan dan pembelajaran akan menjadi berkualitas apabila mampu melahirkan keunggulan akademik yang sesuai dengan kompetensi personal maupun institusional yang dinyatakan lulus uji kompetensi pada setiap jenjang pendidikan dalam menyelesaikan program-program pembelajaran. 
Aplikasi manajemen strategis peningkatan mutu Pendidikan Tinggi didasarkan atas pemikiran bahwa kerangka kerja yang diterapkan oleh pimpinan perguruan tinggi harus dipilih secara tepat agar mampu memperbaiki mutu dan kinerja lembaga yang didasarkan pada pencapaian visi dan misi yang dimiliki oleh perguruan tinggi. Visi dan misi perguruan tinggi dapat dijadikan sebagai dasar dalam meningkatkan mutu pendidikan. Penerapan manajemen stratejik di lembaga pendidikan memilki keputusan yang tepat untuk mencapai rencana yang bermuara kepada tujuan lembaga pendidikan (Iskandar, 2017:269). Mutu pendidikan tinggi dapat ditingkatkan menjadi lebih baik dengan memperhatikan prinsip-prinsip mendasar sebagai berikut: (1) peningkatan mutu berorientasi pada kepuasan pelanggan, (2) pelanggan yang ada di lembaga pendidikan adalah setiap orang yang memperoleh layanan, baik internal maupun eksternal yang ada dalam organisasi lembaga pendidikan tinggi, (3) mutu lembaga pendidikan tinggi harus sesuai dengan kebutuhan stakeholder dan standar yang telah ditetapkan, (4) mutu pendidikan dapat dicapai apabila manajer dan organisasi mampu mencegah kinerja yang tidak sesuai dengan standar, bukan dengan cara mencari sebab terjadinya kegagalan, melainkan dengan cara peningkatan mutu layanan dan kinerja secara berkelanjutan, (5) pimpinan puncak harus mampu mengendalikan mutu perguruan tinggi yang didukung oleh semua yang ada dalam sistem organisasi, sehingga semua anggota organisasi juga mempunyai tanggung jawab dalam setiap proses peningkatan mutu, (6) statistik dijadikan alat untuk mengukur mutu, (7) terdapat kerja sama tim yang efektif dalam meningkatkan mutu, serta (8) melaksanakan pendidikan dan pelatihan dalam upaya mencapai mutu (Bennet, Crawford, dan Riches, 1992:99).

Integrasi berbagai faktor yang berkaitan dengan pelanggan, kepemimpinan, tim, proses, dan struktur dapat dijadikan dasar dalam formulasi strategi peningkatan mutu perguruan tinggi (Mantja , 2002:75). Pelanggan pendidikan tinggi berkaitan dengan yang menerima lulusan atau yang menggunakan jasa layanan di perguruan tinggi baik internal maupun eksternal. Pengguna atau pelanggan perguruan tinggi harus memahami tentang: visi dan misi perguruan tinggi, nilai-nilai yang dijalankan dalam pengambilan keputusan, dan perencanaan kegiatan yang menjadi program pencapaian mutu. Kepemimpinan merupakan faktor kunci dalam melaksanakan manajemen strategik. Pimpinan perguruan tinggi, dekan, dan ketua jurusan harus mampu dan menguasai berbagaimacam strategi dalam meningkatkan mutu pendidikan tinggi. Leader perguruan tinggi harus dapat menetapkan, melaksanakan, dan mengendalikan visi serta misi perguruan tinggi. Kondisi yang demikian ini menuntut leader agar mempunyai visi, misi, kreativitas, sensitivitas, pemberdayaan (empowerment), dan memahami tentang perubahan dan perkembangan dunia pendidikan tinggi baik regional, nasional, dan internasioal. Tim merupakan sarana yang harus dibangun oleh leader di perguruan tinggi dalam miningkatkan mutu kinerja yang produktif. Kinerja tim menekankan adanya kejelasan tujuan, wewenang, dan hubungan interpersonal yang efektif dalam mewujudkan kinerja tim yang yang efektif dan produktif. Proses kerja dalam meningkatkan mutu pendidikan merupakan hal yang sangat penting untuk diperhatikan, karena hasil sangat ditentukan pelaksanaan proses yang terjadi dalam organisasi lembaga pendidikan tinggi. Struktur sebagai langkah dalam melaksanakan kinerja sesuai dengan garis kewenangannya masing-masing anggota organisasi dalam sistem manajemen strategik upeningkatan mutu pendidikan tinggi di IAIN.

Formulasi strategi dalam lembaga pendidikan berkaitan erat dengan penetapan misi organisasi, asesmen lingkungan internal dan eksternal organisasi, menetapkan arah dan sasaran atau tujuan, dan menentukan strategi (Sutikno, 2013:90). Formulasi strategi dalam meningkatkan mutu IAIN perlu memperhatikan hal-hal sebagai berikut: commitment, communacation, dan culture. Komitmen dan komunikasi menjadikan suatu yang sangat penting untuk diciptakan dalam sistem organisasi lembaga pendidikan dalam mewujudkan mutu lembaga pendidikan.

Budaya yang ada di perguruan tinggi berkaitan dengan filosofi organisasi, perilaku, aturan, norma, asumsi, serta nilai-nilai yang dianut dan dijalankan oleh seluruh anggota organisasi. Keberhasilan pelaksanaan manajemen strategik ditentukan oleh penciptaan budaya yang ada di perguruan tinggi, seperti adanya: (1) inovasi dalam pendidikan dan pembelajaran, (b) performansi dan kontribusi dosen dantenaga kependidikan, (c) kepemimpinan adalah kunci keberhasilan, (d) penghargaan kinerja, (e) adanya pengembangan, belajar dan pelatihan dalam melaksanakan kinerja, (f) pemberdayaan sumberdaya potensial baik manusia dan non manusia untuk mencapai tujuan, dan (g) adanya perbaikan dan pengembangan yang dijalankan secara terus-menerus sebagai iklim organisasi (Mutohar dan Masduki, 2018:75). Institut Agama Islam Negeri sebagai lembaga pendidikan tinggi Islam harus dikembangkan secara berkelanjutan (continous quality improvement) agar strategi dalam peningkatan mutu pendidikan tinggi dapat tercapai dengan baik dan terkendali serta lebih diminati oleh masyarakat dan stakeholders pendidikan baik pada tingkat regional, nasional, bahkan internasional sehingga memiliki daya saing yang tinggi di era glonal yang terjadi pada saat ini.

Peningkatan mutu pendidikan tinggi harus sesuai dengan standar mutu, kebutuhan dan 
harapan masyarakat, serta pencapain visi dan misi yang akan diwujudkannya dalam proses pendidikan yang diselenggarakan di perguruan tinggi. Pendidikan yang bermutu pada hakekatnya mampu menghasilkan lulusan yang memiliki kompetensi akademik, kejuruan, sosial, dan personal yang sesuai dengan standar mutu yang dapat dijadikan sebagai kecakapan hidup (life skill) lulusan perguruan tinggi. Peningkatan mutu pendidikan harus diikuti dengan penataan kelembagaan berdasarkan penerapan manajemen yang sesuai agar mampu mencapai tujuan secara efektif dan efisien. Upaya peningkatan mutu perguruan tinggi dapat menggunakan pendekatan strategis dengan mengintegrasikan beberapa aspek manajemen untuk mengatur dan menentukan strategi pencapaian visi, misi, dan tujuan institusi perguruan tinggi.

Penelitian ini dilaksanakan di Institut Agama Islam Negeri (IAIN) Tulungagung, IAIN Jember, dan IAIN Ponorogo. Penelitian ini diharapkan dapat menghasilkan teori tentang formulasi strategik dalam peningkatan mutu dan daya saing IAIN sebagai lembaga pendidikan tinggi PTKIN di Indonesia. Hasil dari penelitian ini dapat dijadikan sebagai dasar untuk mengadakan pembinaan dan pengembangan IAIN di Indonesia untuk meningkatkan mutu dan daya saing lembaga sehingga diminati oleh masyarakat dan pengguna lulusan. Mutu dan daya saing merupakan hal yang sangat penting untuk diperhatikan dalam upaya untuk memenuhi kebutuahan dan kepuasan pelanggan pendidikan tinggi. Kebutuhan dan kepusan pelanggan merupakan jaminan kepercayaan yang secara terus-menerus harus diperhatikan oleh lembaga pendidikan Islam agar dapat diminati oleh masyarakat dan stakeholders pendidikan.

\section{B. METODE PENELITIAN}

Tujuan penelitian ini adalah untuk mendapatkan gambaran secara mendalam tentang formulasi strategi peningkatan mutu IAIN di Jawa Timur. Pendekatan kualitatif dipandang tepat untuk digunakan dalam mencapai tujuan tersebut. Data penelitian dikumpulkan secara alami (natural setting) yaitu di IAIN Tulungagung, IAIN Jember, dan IAIN Ponorogo sebagai sumber data langsung. Agar tujuan tersebut bisa tercapai dengan baik, maka penelitian ini menggunakan rancangan studi multi situs (Yin, 1984; Bogdan \& Biklen, 1998). Agar mendapatkan data penelitian yang sesuai dengan fokus, maka digunakan tehnik pengumpulan data: wawancara mendalam (indepth interview), observasi partisipan (participant obsevation), dan studi dokumentasi (study of dokuments) (Bogdan \& Biklen, 1982). Tehnik pengumpulan data ini digunakan untuk memperoleh data-data yang valid dan dapat dipertanggung jawabkan dalam proses penelitian.
Data yang terkumpul dalam penelitian ini dapat dikelompokkan menjadi data primer dan data skunder. Data primer berbentuk kata-kata dan tindakan yang dilakukan oleh informan di IAIN berdasarkan fokus penelitian. Adapun data-data skunder dapat berbentuk dokumentasi yang bisa memperkuat data primer untuk mendapatkan validitas dan releabilitas pemerolehan data dalam penelitian ini. Key informan dalam penelitian ini adalah pimpinan dari masing-masing perguruan tinggi dan selanjutnya dalam menjaring data yang lebih luas dan mendalam digunakan tehnik snowball sampling atau sampel guliran bola salju. Tehnik ini dilaksanakan dengan cara informan kunci diminta untuk menunjuk orang-orang yang mengetahui masalah yang akan diteliti untuk melengkapi keterangannya dan orang-orang yang ditunjuk akan menunjuk orang lain lagi untuk memberikan informasi berikutnya, begitu juga seterusnya sampai penelitian ini selesai atau data sudah tidak bisa didapatkan lagi (jenuh). Untuk menjamin adanya validitas data penelitian, maka digunakan tehnik: (1) trianggulasi sumber dan metode, (2) pengecekan anggota (member check), diskusi teman sejawat (peer reviewing), dan (3) pengecekan kecukupan referensi/ referencial adequasy check, (Lincoln dan Guba, 1985).

Analisis data dilaksanakan dengan mengatur secara sistematis terhadap transkrip wawancara, dokumentasi, dan catatan hasil observasi yang kemudian ditata, dikelompokkan, ditelaah dibagi menjadi satuan-satuan tema yang disusun secara sistematis sebagai temuan penelitian. Adapun proses analisis data dilaksanakan berdasarkan alur kegiatan sebagai berikut: (1) reduksi data, merupakan kegiatan analisis yang bertujuan untuk menajamkan, menggolongkan, mensortir data, dan mengorganisasi data supaya diperoleh kesimpulan akhir dan verifikasi. Reduksi data dilaksanakan selama penelitian berlangsung, (2) penyajian data, kegiatan ini dilaksanakan untuk menemukan pola-pola yang bermakna serta memberikan kemungkinan adanya penarikan kesimpulan dan pengambilan tindakan, dan (3) peneliti melaksanakan penarikan kesimpulan atau verifikasi (Miles \& Huberman, 1992).

\section{HASIL PENELITIAN DAN PEMBAHASAN}

Formulasi strategi peningkatan mutu IAIN di Jawa Timur merupakan kegiatan yang ditempuh oleh lembaga dalam membuat programprogram strategis lembaga dalam mendayagunakan seluruh sumber daya potensial yang dimiliki untuk mencapai tujuan yang telah ditetapkan dan menjadi komitmen bersama. Hal ini sangat penting untuk diperhatikan oleh lembaga pendidikan Islam untuk mencapai visi, misi, dan tujuan organisasi yang menjadi kesepakatan bersama. Tujuan yang telah ditetapkan harus dicapai dengan baik agar perguruan tinggi yang bermutu dan memiliki daya 
saing yang tinggi dapat direalisasikan dengan baik. Hal ini dimaksudkan agar lembaga pendidikan Islam mampu bersaing dan memenuhi tuntutan, kebutuhan, dan kepuasan pelanggan agar diminati oleh masyarakat secara luas baik pada tingkat regional, nasional, bahkan internasional.

Mutu dan daya saing perguruan tinggi merupakan kata kunci yang harus diwujudkan oleh setiap perguruan tinggi agar dapat diminati oleh masyarakat dan pengguna lembaga pendidikan. Untuk mewujudkan perguruan tinggi yang bermutu dan berdaya saing tinggi perlu adanya formulasi strategi yang dapat digunakan dalam meningkatkan mutu dan daya saing. Temuan penelitian yang berkaitan dengan formulasi strategi dalam meningkatkan mutu IAIN di Jawa Timur dapat diberikan penjelasan dalam bentuk gambar sebagai berikut: tersebut diatas, maka diharapakan mampu menjadi lembaga pendidikan yang bermutu dan berdaya saing di era global yang terjadi pada saat ini.

Visi, Misi, dan Tujuan IAIN dijadikan sebagai dasar dalam perumusan Formulasi Strategi dalam meningkatkan mutu dan daya saing IAIN di Jawa Timur. Perumusan peningkatan mutu didesain untuk mencapai impian, harapan, dan cita-cita yang telah dirumuskan dan menjadi kesepakatan serta komitmen bersama untuk mewujudkannya dengan baik. Agar harapan dan impian ini bisa tercapai dengan baik, maka langkah strategis yang dilaksanakan oleh lembaga adalah: (1) identifikasi kekuatan dan kelemahan lembaga secara obyektif agar mampu mendayagunakan kekuatan dengan baik serta membuat kebijakan dalam mengatasi kelemahan yang ada dalam lembaga pendidikan tinggi, (2) idnetifikasi peluang dan hambatan yang ada dalam meningkatkan mutu dan daya saing IAIN di Jawa Timur. Peluang perlu dirumuskan strategi

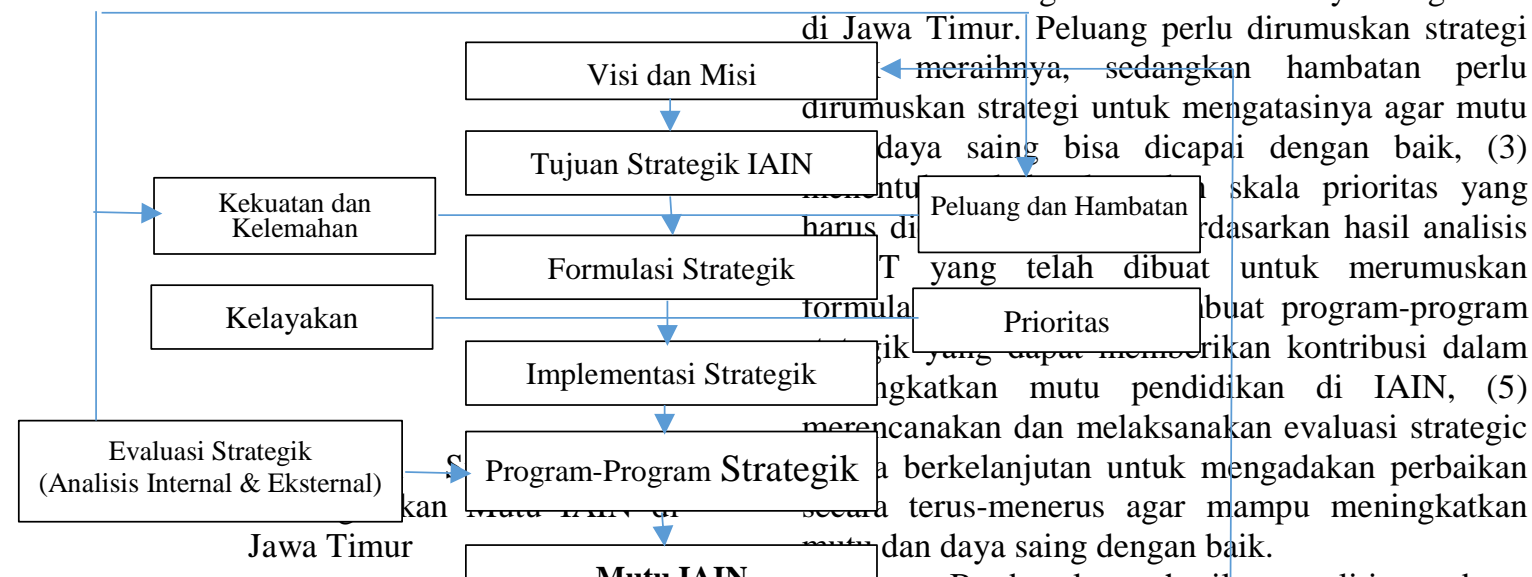
Jawa Timur Mutu IAIN $\quad \begin{gathered}\text { Berdasarkan hasil penelitian dapat } \\ \text { Ben }\end{gathered}$ dijelaskan bahwa formulasi strategi peningkatan mutu dan daya saing IAIN di Jawa Timur secara garis besar difokuskan pada dua hal, yaitu: (1) penguatan bidang akademik (core activities of Higher Education); dan (2) Penguatan bidang nonakademik (supporting activities of Higher Education). Perencanaan penguatan bidang akademik (core activities of Higher Education) yang diselenggarakan di IAIN Jawa Timur berkaitan erat dengan hal-hal sebagai berikut: (a) rekrutmen calon mahasiswa baru, (b) penguatan bidang pendidikan, (c) penguatan bidang penelitian; dan (d) penguatan pengabdian kepada masyarakat. Sementara, penguatan bidang non-akademik (supporting activities of Higher Education), meliputi (a) penguatan bidang sarana dan prasarana pendidikan, (b) penguatan pengelolaan sumber daya manusia dosen dan tenaga kependidikan, (c) penguatan tatakelola perguruan tinggi dan manajemen, (d) penguatan bidang pembentukan citra positif kelembagaan IAIN di Jawa Timur, (e) penguatan bidang Sistem Informasi manajemen dan Teknologi Informasi, (f) penguatan bidang kerjasama, dan $(\mathrm{g})$ penguatan bidang pembiayaan pendidikan. 
Penguatan bidang akademik mendapatkan perhatian yang sangat serius oleh pimpinan IAIN di Jawa Timur. Akademik merupakan inti dalam penyelenggaraan pendidikan tinggi. Mahasiswa harus menguasai seperangkat ilmu pengetahuan yang menjadi kurikulum dalam setiap program studi. Mahasiswa harus mempunyai kompetensi akademik yang sesuai dengan standar kompetensi yang ada dalam masing-masing program studi. Berdasarkan hasil analisis terhadap data-data yang diperoleh tentang penguatan akademik IAIN di Jawa Timur dapat diberikan penjelasan dalam bentuk tabel sebagai berikut:

Tabel 1.1: Penguatan Bidang Akademik Institut Agama Islam Negeri (IAIN) di Jawa Timur

\begin{tabular}{|l|c|c|c|}
\hline \multirow{2}{*}{$\begin{array}{l}\text { Penguatan } \\
\text { Bidang } \\
\text { Akademik }\end{array}$} & \multicolumn{3}{|c|}{ Kategori } \\
\cline { 2 - 4 } & Tulungagung & $\begin{array}{c}\text { IAIN } \\
\text { Jember }\end{array}$ & $\begin{array}{c}\text { IAIN } \\
\text { Ponorogo }\end{array}$ \\
\hline $\begin{array}{l}\text { Rekrutmen } \\
\text { calon } \\
\text { mahasiswa } \\
\text { baru }\end{array}$ & Sangat Baik & $\begin{array}{c}\text { Sangat } \\
\text { Baik }\end{array}$ & Baik \\
\hline $\begin{array}{l}\text { Penguatan } \\
\text { bidang } \\
\text { pendidikan }\end{array}$ & Sangat Baik & $\begin{array}{l}\text { Sangat } \\
\text { Baik }\end{array}$ & $\begin{array}{c}\text { Sangat } \\
\text { Baik }\end{array}$ \\
\hline $\begin{array}{l}\text { Penguatan } \\
\text { bidang } \\
\text { penelitian }\end{array}$ & Sangat Baik & $\begin{array}{l}\text { Sangat } \\
\text { Baik }\end{array}$ & $\begin{array}{c}\text { Sangat } \\
\text { Baik }\end{array}$ \\
\hline $\begin{array}{l}\text { Penguatan } \\
\text { pengabdian } \\
\text { kepada } \\
\text { masyarakat }\end{array}$ & Sangat Baik & $\begin{array}{l}\text { Sangat } \\
\text { Baik }\end{array}$ & $\begin{array}{c}\text { Sangat } \\
\text { Baik }\end{array}$ \\
\hline
\end{tabular}

Sumber: Hasil analisis data penelitian

Penguatan dalam bidang akademik yang dimulai dari rekrutmen mahasiswa baru IAIN di Jawa Timur menunjukkan bahwa telah dilaksanakan dalam kondisi sangat baik dan peminat dari tahun ke tahun mengalami peningkatan yang cukup signifikan. Hal ini disebabkan karena adanya upaya yang ditempuh oleh lembaga untuk mengadakan penguatan dalam bidang pendidikan dan pembelajaran, penelitian, serta pengabdian masyarakat. Dosen sebagai ujung tombak dalam melaksanakan tridharma perguruan tinggi telah diberdayakan dengan baik, sehingga juga dapat memperkuat pelaksanaan proses pembelajaran yang dapat membentuk kompetensi mahasiswa. Perbaikan dan peningkatan mutu dilaksanakan secara terus-menerus (continous quality improvement) agar IAIN di Jawa Timur mampu meningkatkan mutu dan mampu bersaing secara kompetitif agar tidak ditinggalkan oleh pelanggan atau peminat terhadap eksistensi lima IAIN di Jawa Timur.

Penguatan bidang non akademik juga dilaksanakan secara bersamaan dengan penguatan bidang akademik, karena menjadi faktor pendukung terjadinya percepatan peningkatan mutu IAIN di Jawa Timur. Berdasarkan hasil analisis dan temuan penelitian menunjukkan bahwa pelaksanaan penguatan bidang non akademik dapat dilihat dalam bentuk tabel sebagai berikut:

Tabel 1.2: Penguatan Bidang Non Akademik Institut Agama Islam Negeri (IAIN) di Jawa Timur

\begin{tabular}{|c|c|c|c|}
\hline \multirow{2}{*}{$\begin{array}{c}\text { Penguatan } \\
\text { Bidang Non- } \\
\text { Akademik }\end{array}$} & \multicolumn{3}{|c|}{ Kategori } \\
\hline & $\begin{array}{c}\text { IAIN } \\
\text { Tulungagun } \\
\mathrm{g} \\
\end{array}$ & $\begin{array}{c}\text { IAIN } \\
\text { Jembe } \\
\mathrm{r}\end{array}$ & $\begin{array}{c}\text { IAIN } \\
\text { Ponorog } \\
\text { o } \\
\end{array}$ \\
\hline $\begin{array}{l}\text { Sarana \& } \\
\text { prasarana } \\
\text { pendidikan } \\
\end{array}$ & Sangat Baik & $\begin{array}{l}\text { Sangat } \\
\text { Baik }\end{array}$ & $\begin{array}{l}\text { Sangat } \\
\text { Baik }\end{array}$ \\
\hline $\begin{array}{l}\text { Pengelolaan } \\
\text { sumber daya } \\
\text { manusia } \\
\text { (dosen \& } \\
\text { tenaga } \\
\text { kependidikan } \\
\text { ) }\end{array}$ & Baik & Baik & Baik \\
\hline $\begin{array}{l}\text { Tatakelola } \\
\text { organisasi \& } \\
\text { manajemen }\end{array}$ & Baik & Baik & Baik \\
\hline $\begin{array}{l}\text { Pembentukan } \\
\text { citra positif } \\
\text { kelembagaan }\end{array}$ & Sangat Baik & $\begin{array}{c}\text { Sangat } \\
\text { Baik }\end{array}$ & $\begin{array}{c}\text { Sangat } \\
\text { Baik }\end{array}$ \\
\hline $\begin{array}{l}\text { Sistem } \\
\text { Informasi \& } \\
\text { Teknologi } \\
\text { Informasi }\end{array}$ & Baik & Baik & Baik \\
\hline $\begin{array}{l}\text { Bidang } \\
\text { kerjasama }\end{array}$ & Sangat Baik & $\begin{array}{c}\text { Sangat } \\
\text { Baik }\end{array}$ & Baik \\
\hline $\begin{array}{l}\text { Pembiayaan } \\
\text { pendidikan }\end{array}$ & Baik & Baik & Baik \\
\hline
\end{tabular}

Sumber: Hasil analisis data penelitian

Berdasarkan data tersebut dapat diberikan penjelasan bahwa penguatan dalam bidang non akademik berkaitan erat dengan sarana dan prasarana pendidikan selalu ditingkatkan secara terus-menerus sehingga dalam kondisi sangat baik, begitu juga pengelolaan sumber daya manusia baik dosen maupun tenaga kependidikan dan tata kelola organisasi juga selalu ditingkatkan sehingga berada pada kondisi baik, selain itu juga upaya untuk membentuk citra positif lembaga juga dilaksanakan dengan sangat baik yang mengakibatkan peminat mahasiswa barus selalu mengalami peningkatan dari tahun ketahun, sistem informasi dan tehnologi informasi juga terus ditingkatkan dengan menyediakan sumber daya yang potensial untuk membuat dan menjalankan sistem informasi manajemen kampus yang bagus dan dapat dipertanggung jawabkan dengan baik, bidang kerjasama juga selalu ditingkatkan baik kerja sama dengan luar negeri maupun dalam negeri yang dapat memberikan kontribusi positif dalam mengembangkan lembaga dan meningkatkan mutu pendidikan IAIN di Jawa Timur, bidang pembiayaan juga ditingkatkan dan diperbaiki secara 
terus-menerus agar mampu membuat akuntabilitas dengan baik serta mendapat kepercayaan yang tinggi baik dari pemerintah maupun masyarakat pengguna lembaga pendidikan di IAIN Jawa Timur.

Peningkatan mutu pendidikan tinggi dapat dilaksanakan dengan adanya perbaikan mutu secara terus-menerus yang sering disebut dengan istilah continuous quality improvement, perbaikan mutu yang dilaksanakan di IAIN tanpa ada kata henti dalam menjalankan proses peningkatan mutu pendidikan tinggi agar bisa menjadi berkualitas. Hal ini disebabkan karena ilmu pengetahuan dan kebutuhan stakeholder pendidikan juga meningkat secara terus-menerus sesuai dengan perkembangan ilmu pengetahuan dan tehnologi. Sehingga sangat tepat apabila Danim (2006:39) memberikan penjelasan bahwa tidak ada kata berhenti untuk sebuah proses, tidak ada kata final untuk sebuah perubahan, karena yang ada adalah proses menuju ke arah kesejatian ideal yang abstraktif. Kondisi ideal harus diupayakan untuk bisa dicapai dengan baik dalam sistem organisasi perguruan tinggi. Hambatan dan kendala pasti akan ada dalam menjalankan proses organisasi lembaga pendidikan. Oleh karena itu, formulasi strategi sangat dibutuhkan oleh lembaga dalam mengatasi hambatan dan kendala yang terjadi sehingga perguruan tinggi mampu mencapai visi dan misi dengan baik sesuai dengan tahapan-tahapan pencapaian yang telah dirumuskan.

$$
\text { Murgantroyd dan Morgan (1994) }
$$

memberikan penjelasan tentang strategi dalam menetapkan mutu, yaitu: (1) menetapkan standar mutu dalam sistem Quality Assurance. Proses peaksanaan, pengawasan, dan evaluasi programprogram kegiatan yang ada di perguruan tinggi dilaksanakan berdasarkan standar mutu perguruan tinggi, (2) Contract Conformance, standar mutu perguruan tinggi ditetapkan Analisis kan kesepakatan bersama dalam ber Lingkungan uan bersama dalam meningkatkan Internal tinggi. Standar mutu_danat diiadikg (Kekuatan dan lok ukur dalam proses Misi mu Kelemahan perguruan tinggi, Organisasi ner- Analisis lity berkaitan erat deng_an 1 and Lingkungan nya dari mereka yang menerima out-pus Eksternal uan tinggi atau pemakai lulusan. Kuali (Peluang dan dari perguruan tinggi harus sesuai deng Ancaman dan kebutuhan pelanggan atau stakeholder perifdidikan.

Formulasi strategi peningkatan mutu perguruan tinggi merupakan proses kegiatan yang berisi tentang pemikiran, pemilihan strategi, penentuan strategi, dan sebagainya yang semuanya itu dilakukan dalam rangka tercapainya tujuan yang telah ditetapkan di perguruan tinggi (Rohiat, 2009:44). Formulasi strategi berkaitan erat dengan proses pengambilan keputusan yang ada di perguruan tinggi atas sejumlah alternatif yang berkaitan dengan sasaran dan strategi yang dapat digunakan untuk mencapai tujuan secara efektif dan efisien yang disertai dengan cara pemantauan dan penilaiannya atas hasil pelaksanaan suatu kegiatan secara sistematis dan berkesinambungan. Kegiatan formulasi strategi membutuhkan analisis lingkungan internal dan analisis lingkungan eksternal yang dapat dijadikan sebagai dasar untuk mengambil keputusan-keoputusan strategis di lembaga pendidikan tinggi agar tujuan-tujuan strategis bisa tercapai secara efektif dan efisien.

Formulasi strategi dalam meningkatkan mutu perguruan tinggi keagamaan Islam merupakan kegiatan yang sangat penting untuk mengambil keputusan strategis pada jangka pendek, menengah, dan jangka panjang dalam sistem organisasi perguruan tinggi. Formulasi strategi dalam penyusunan perencanaan dilaksanakan dengan menggunakan proses analisis SWOT yang didasarkan pada data-data riel yang dimiliki oleh perguruan tinggi. Proses analisis dalam kegiatan formulasi strategi dibutuhkan agar organisasi mampu menentukan dan memilih strategi yang tepat dalam mencapai tujuan (Rangkuti, 2004: 8). Formulasi strategi yang berkaitan dengan kepuasan pelanggan menjadi fokus perhatian utama dalam menerapkan manajemen stratejik peningkatan mutu pendidikan tinggi IAIN di Jawa Timur. Oleh karena itu penggunaan konsep kepuasan pelanggan harus menjadi dasar pengambilan kebijakan dalam meningkatkan mutu IAIN di Jawa Timur. Berkaitan dengan hal tersebut, Kotler dan Keller (2009: 51) menjelaskan tentang langkah-langkah formulasi strategis dalam meningkatkan mutu organisasi sebagai berikut:

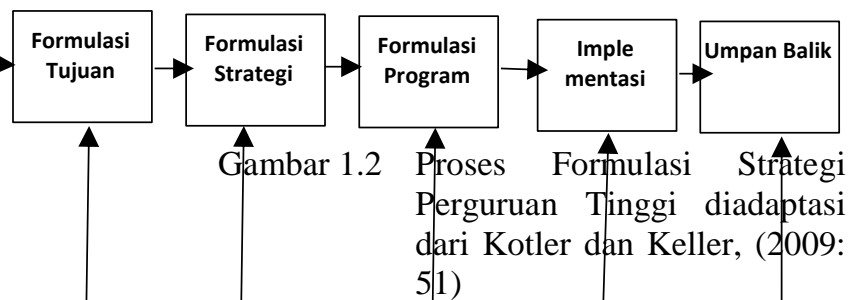

Berdasarkan gambar tentang proses formulasi strategi perguruan tinggi dalam meningkatkan mutu dan daya saing pendidikan tinggi dapat diberikan penjelasan bahwa: Misi Organisasi Perguruan Tinggi termasuk IAIN harus dirumuskan secara spesifik dalam rangka untuk mencapai visi lembaga pendidikan tinggi yang telah menjadi kesepakatan bersama. Visi merupakan impian yang akan dicapai oleh lembaga pendidikan di masa yang akan datang. Berkaitan dengan visi ini, Bennis dan Nanus memberikan definis visi 
sebagai: some think that articulates a view of a realistic, credible, attractive future for the organizatinon, a condition that is better in some important ways than what now exist (Akdon, 2006:96). Komariah dan Triatna (2006: 91) mengungkapkan ciri-ciri visi yang baik sebagai berikut: (a) memperjelas arah dan tujuan, (b) mudah dimengerti dan diartikulasikan, (c) mencerminkan cita-cita yang tinggi dan menerapkan standar of excellence, (d) menumbuh inspirasi, semangat, kegairahan dan komitmen, (e) menciptakan makna bagi anggota organisasi, (f) merefleksikan keunikan atau keistimewaan organisasi, (g) menyiratkan nilai-nilai yang dijunjung tinggi oleh organisasi, (h) kontekstual dalam arti memperhatikan secara seksama hubungan organisasi.

Agar visi yang dimiliki oleh IAIN menjadi operasional, perlu juga dirumuskan misi. Pernyataan dalam misi lebih tajam dan lebih detail sebagai jabaran perumusan visi organisasi lembaga pendidikan tinggi. Proses dalam perumusan misi organisasi, dimulai dari perumusan kata kunci yang ada dalam visi organisasi yang telah dirumuskan. Kata kunci dalam pencapaian visi perlu ditentukan indikator yang akan dirumuskan menjadi misi. Indikator-indikator tersebut dapat dijadikan sebagai acuan dalam perumusan misi organisasi lembaga pendidikan. Visi yang dimiliki oleh IAIN di Jawa Timur juga dijabarkan dalam bentuk misi yang akan dicapai berdasarkan tahapan-tahapan strategi yang menjadi kebijakan lembaga. Misi IAIN ini sangat penting untuk mencapai tujuan yang ingin dicapai sebagai cita-cita dan harapan bersama. Upaya untuk mencapai visi dan misi perguruan tinggi, IAIN sebagai lembaga pendidikan tinggi perlu mengadakan analisis lingkungan internal dan eksternal dalam merumuskan formulasi strategi.

Analisis Lingkungan Ekstemal berkaitan erat dengan peluang dan ancaman perguruan tinggi. Perguruan tinggi sebagai organissi lembaga pendidikan harus dapat mengetahui dengan pasti peluang dan ancaman yang datang dari eksternal organisasi. Hal ini dalam rangka untuk mengetahui peluang yang bisa diperoleh dalam meningkatkan mutu IAIN di Jawa Timur. Selain peluang, juga untuk mengetahui ancaman yang datang dari luar organisasi yang dapat mempengaruhi kelancaran jalannya organisasi atau yang dapat menghalangi kemajuan organisasi. Ancaman ini harus diselesaikan atau dihindari agar tidak menghambat perkembangan perguruan tinggi. Analisis Lingkungan Eksternal (ALE) dalam organisasi perguruan tinggi berkaitan erat dengan kondisi, situasi, keadaan, peristiwa, dan pengaruh-pengaruh yang berasal dari luar lembaga yang mempunyai dampak baik secara langsung maupun tidak langsung terhadap lembaga perguruan tinggi. Lingkungan eksternal organisasi perguruan tinggi ini berkaitan erat dengan: (a) peluang (opportunity), yaitu situasi dan kondisi serta faktor-faktor yang ada diluar organisasi yang bersifat positif yang bisa membantu mencapai visi dan misi perguruan tinggi, (b) tantangan atau ancaman, merupakan faktorfaktor yang terdapat diluar organisasi perguruan tinggi yang bersifat negatif sehingga dapat mengakibatkan perguruan tinggi mengalami kegagalan atau hambata dalam mencapai visi dan misi yang telah ditetapkan (Akdon, 2006:112).

Analisis Lingkungan Internal IAIN di Jawa Timur dilaksanakan dalam rangka untuk mengetahui kekuatan dan kelemahan organisasi perguruan tinggi. Agar IAIN di Jawa Timur bisa sukses untuk meraih peluang, maka perlu mengetahui kekuatan yang dimiliki untuk diberdayakan dalam meraih peluang, sehingga visi dan misi Perguruan Tinggi dapat diraih dengan baik. Selain mengetahui kekuatan juga perlu diketahui kelemahan organisasi Perguruan Tinggi dengan baik dan tepat. Mengetahui kelemahan dapat dijadikan sebagai dasar untuk membuat kebijakan strategis dan skala prioritas dalam perbaikan organisasi. Kelemahan harus diperbaiki agar perguruan tinggi mampu untuk meraih peluang dengan baik, peluang akan sangat sulit untuk diraih, apabila perguruan tinggi masih mempunyai banyak kelemahan. Oleh karena itu, analisis lingkungan internal organisasi perguruan tinggi ini sangat dibutuhkan agar leader dapat membuat kebijakan strategis yang berorientasi pada peningkatan mutu IAIN di Jawa Timur. Faktor internal yang terdapat di IAIN juga berkaitan dengan seluruh situasi dan kondisi kehidupan kampus yang dapat dikendalikan baik oleh rector, dekan, ketua lembaga, dan pimpinan yang lainnya maupun oleh anggota organisasi yang ada di perguruan tinggi. Secara rinci faktor-faktor yang dimaksudkan berkaitan erat dengan: (1) visi, misi, sasaran, dan tujuan organisasi, (2) strategi pencapaian tujuan, (3) jenis dan sifat kegiatan, (4) jenis teknologi yang digunakan (Fahmi, 2015:102). Kegiatan analisis lingkungan internal perguruan tinggi berkaitan erat dengan upaya untuk mengetahui strategi yang bisa digunakan dalam mencapai Visi, Misi, Sasaran, dan Tujuan organissi perguruan tinggi. Organisasi perguruan tinggi dituntut untuk memiliki visi, misi, sasaran dan tujuan yang ingin dicapainya, tanpa adanya visi, misi dan tujuan yang jelas di perguruan tinggi, lembaga akan mengalami kesulitan untuk diarahkan (Iriantara, 2009).

Formulasi Tujuan IAIN di Jawa Timur dibuat dan dirumusakan setelah membuat analisis SWOT. Perguruan tinggi dapat mengembangkan tujuan khusus dalam suatu periode perencanaan atau bisa disebut dengan perencanaan jangka pendek. Tahap ini dalam manajamen strategik sering disebut dengan istilah formulasi tujuan (goal formulation). Tujuan perguruan tinggi adalah sasaran yang spesifik yang berkaitan dengan besaran tujuan yang ingin dicapai dan waktu pelaksanaannya. Sasaran atau tujuan merupakan hal 
yang sangat penting untuk dirumuskan karena akan menjadi fokus dalam pelaksanaan seluruh proses pendidikan dan pembelajaran yang ada di perguruan tinggi. Pelaksanaan terfokus ini dalam sistem manajemen sering disebut dengan Management by Objectives (MBO). Formulasi strategi ini pada hakekatnya merupakan sebuah kegiatan dalam membuat perencanaan strategis. Perencanaan merupakan suatu proses dalam menentukan tujuan atau sasaran yang akan dicapai dalam organisasi, serta menetapkan cara dan sumber yang diperlukan dalam mencapai tujuan secara efektif dan efisien di perguruan tinggi (Djumberansjah, 1995:3).

Formulasi Strategi perguruan tinggi pada hakekatnya adalah tujuan (goal) untuk mengetahui secara pasti terhadap segala sesuatu yang akan dicapai oleh perguruan tinggi pada kurun waktu tertentu. Adapun strategi merupakan sebuah rencana yang dibuat oleh perguruan tinggi untuk mensiasati agar tujuan yang telah ditetapkan dapat dicapai dengan baik. Perguruan tinggi hasrus membuat strategi untuk mencapai tujuan yang telah ditetapkan berdasarkan tahapan-tahapan strategis yang telah diambil kebijakan oleh leader di perguruan tinggi. Formulasi strategi sebagai suatu proses intelektual untuk menentukan secara sadar tindakan-tindakan yang akan ditempuh yang didasarkan pada keputusan-keputusan strategi yang berorientasi pada pencapaian tujuan pada setiap tahapan strategi. Formulasi strategi ini akan dapat memberikan informasi yang tepat waktu dan dapat dipercaya, serta memperhatikan perkiraan keadaan yang akan dicapai dimasa yang akan datang. Untuk itu dalam kegiatan formulasi strategi atau dalam kegiatan perencanaan membutuhkan pendekatan rasional kearah tujuan yang telah ditetapkan sebelumnya (Fatah, 2004: 50).

Formulasi dan Implementasi Program Strategik perguruan tinggi yang dipandang sangat baik dapat juga mengalami kegagalan untuk diwujudkan apabila implementasinya tidak baik. Apabila perguruan tinggi ingin memperkuat out put-nya mempunyai kompetensi yang bagus dan menguasai bahasa internasional, maka kurikulum harus disusun dengan baik sesuai dengan kompetensi yang diharapkan, ditunjang dengan SDM yang handal dalam bidang keahliannya, mempunyai laboratorium, mengembangkan riset, mengembangkan pembelajaran berbasis life skill, membuat standar mutu, standar proses, srandar penilaian, dan standar kelulusan.

Umpan Balik dan Kendali dalam penyesuaian strategis peningkatan mutu perguruan tinggi dengan lingkungan internal dan ekternal akan menjadi bagus dan tepat apabila dilaksanakan dengan baik dan tepat sasaran. Kondisi yang perlu diperhatikan oleh perguruan tinggi adalah berkaitan erat dengan perubahan dan perkembangan kondisi eksternal yang bisa mengganggu pertumbuhan dan perkembangan perguruan tinggi. Sementara perguruan tinggi juga harus tetap memperhatikan dan berusaha untuk meraih peluang-peluang yang ada sehingga dapat menjadi perguruan tinggi bermutu dan diminati oleh masyarakat. Perguruan tinggi dalam meningkatkan mutu pendidikan perlu juga tetap memperhatikan 7-S, yaitu: strategi, struktur, sistem, style, skill, stef, dan shared value. Kunci kesehatan organisasi lembaga pendidikan tinggi terletak pada kemampuan untuk mempelajari perubahan lingkungan sehingga dapat merumuskan tujuan dan perilaku baru dalam menghadapi situasi dan kondisi yang terjadi agar organisasi bisa berjalan secara efektif dan efisien.

\section{KESIMPULAN}

Berdasarkan hasil penelitian dapat diberikan kesimpulan bahwa formulasi strategi dalam meningkatkan mutu dan daya saing IAIN di Jawa Timur dilaksanakan berdasarkan hasil analisis lingkungan internal dan analisis lingkungan eksternal organisasi serta analisis SWOT yang dilakukan oleh perguruan tinggi. Hasil analisis ini membuat rumusan kebijakan tentang: penguatan bidang akademik dan penguatan non akademik. Penguatan bidang akademik difokuskan mulai dari rekrutmen mahasiswa baru, pelaksanaan pendidikan dan pembelajaran, penelitian, dan pengabdian masyarakat. Penguatan bidang ini akan membuat IAIN di Jawa Timur menjadi bermutu dan diminati oleh masyarakat serta pengguna lembaga pendidikan.

Adapun penguatan bidang non-akademik yang juga bisa disebut sebagai supporting activities of Higher Education berkaitan erat dengan penguatan bidang: sarana dan prasarana pendidikan, pengelolaan sumber daya manusia baik dosen dan tenaga kependidikan, tatakelola IAIN dan manajemen, pembentukan citra positif kelembagaan IAIN di Jawa Timur, Sistem Informasi Manajemen dan Teknologi Informasi dalam keseluruhan sistem yang ada di kampus, kerjasama dalam negeri maupun luar negeri, dan pembiayaan penyelenggaraan pendidikan tinggi. Penguatanpenguatan tersebut didasarkan dari hasil analisis lingkungan internal dan eksternal kampus dalam meningkatkan mutu pendidikan tinggi di IAIN agar menjadi lembaga yang diminati oleh masyarakat dan mampu bersaing dengan lembaga pendidikan tinggi yang lain baik pada tingkat regional, nasional, bahkan internasional.

\section{DAFTAR PUSTAKA}

Akdon, 2006, Strategic Management for Educational Management (Manajemen Strategik untuk Manajemen Pendidikan), Bandung: Alfabeta.

Bennet, N., Crawford, M., \& Riches, C., 1992, Managingange in Education: Individual 
and Organization Perspectives. London: Paul Chapman Publishing Co.

Bogdan, R.C. \& Biklen, S.K., 1998, Qualitative Research for Education: An Introduction to Theory and Methods. London: Allyn and Bacon, Inc.

Bush, T. \& Coleman, M., 2006, Leadership and Strategic Management in Education. Alih Bahasa: Fahrurraji. Jogjakarta: IRCiSoD.

Danim, S., 2006, Visi Baru Manajemen Sekolah dari Unit Birokrasi ke Lembaga Akademik. Jakarta: Bumi Aksara.

Djumberansjah, 1995, Perencanaan Pendidikan, Strategi dan Implementasinya, Surabaya: Karya Abditama.

Fattah, Nanang, 2004. Landasan Manajemen Pendidikan, Bandung: PT. Remaja Rosdakarya

Irfan, Fahmi, 2015, Manajemen Strategis Teori dan Aplikasi. Bandung: ALFABETHA,

Iriantara, Yosal. 2009, Manajemen Humas Sekolah, Bandung: Simbiosa Rekatama Media

Iskandar, Jamaludin, 2017, Penerapan Manajemen Stratejik dalam Meningkatkan Mutu Madrasah. Jurnal Idaarah, Vol.1, No.2, Desember 2017

Kotler dan Keller, 2009, Manajemen Pemasaran. Jilid 1 Edisi 13, Jakarta: Erlangga

Khoiri, Ahmad. 2016, Manajemen Strategik dan Mutu Pendidikan Islam. Manageria: Jurnal Manajemen Pendidikan Islam, Volume 1, Nomor 1, Mei, 2016

Komariah, Aan dan Triatna, Cepi. 2006, Visionary Leadership: Menuju Sekolah Efektif, Jakarta: Bumi Aksara

Lincoln and Guba, 1985, Naturalistic Inquiry, New Delhi: Sage Publication

Mantja, W., 2002, Manajemen Pendidikan dan Supervisi Pengajaran. Malang: Wineka Media.

Miles, M.B. \& Huberman, A.M. 1984, Qualitative Data Analysis A Sources Book of New Methods. Beverly Hill, C.A.: SAGE Publication.

Murgantoyd, S. \& Morgan, C., 1994, Total Quality Management and the School. Buckingham: Open University Press.

Mutohar, Prim M, 2013, Manajemen Mutu Sekolah: Strategi Peningkatan Mutu dan Daya Saing Lembaga Pendidikan Islam. Yogyakarta: AR-RUUZZ MEDIA

Mutohar, Prim M., 2017, Manajemen Pendidikan: Substansi Inti Pengelolaan Lembaga Pendidikan. Tulungagung: IAIN Tulungagun Press

Mutohar, Prim M \& Masduki, 2018. Manajemen Strategik Pendidikan:Staretgi Peningkatan Mutu dan Daya Saing Pendidikan Tinggi. Tulungagung: Cahaya Abadi
Peraturan Menristek Dikti No 44 Tahun 2015 Pasal 3 ayat 1 tentang Standar Nasional Pendidikan Tinggi

Rangkuti, Freddy. 2004, Analisis SWOT; Teknik Membedah Kasus Bisnis: Reorientasi Konsep Perencanaan Strategis untuk menghadapi Abad 21. edisi kesembilan. PT. Gramedia Pustaka Utama. Jakarta.

Rohiat, 2009, Manajemen Sekolah-Teori Dasar dan Praktek, Dilengkapi Dengan Contoh Rencana Strategis dan Rencana Operasional, (Bandung: PT. Refika Aditama.

Sharpe, L. \& Gopinathan, S., 2002, After Effectiveness: New Direction in the Singapore School System, Journal of Education Policy. Vol. 17 No 2: 151166.

Sutikno, Tri Admadji, 2013. Manajemen Strategik Pendidikan Kejuruan dalam Menghadapi Persaingan Mutu. Jurnal Tehnologi dan Kejuruan, Vol. 36, No.1, Pebruari 2013.

Yin, R.K. 1987, Studi Kasus: Desain dan Metode. Alih Bahasa oleh M. Djazi Mudzakir. Jakarta: Raja Grafindo Persada. 